\title{
Asustuspildist muinasaegsel Järvamaal - asustuskeskused ja linnused
}

Priit Lätti

\begin{abstract}
Teesid
Artiklis käsitletakse asustust Järvamaal, ühes Eesti arheoloogiliselt kõige vähem uuritud piirkonnas. Keskendutakse kahele suuremale probleemile - vaadelda asustust keskuste problemaatikast lähtuvalt ning kontrollida senises kirjanduses esitatud oletusi Järvamaa muinasaegse haldusjaotuse kohta. Töö ajalisteks raamideks on rauaaja II pool ning keskaeg, vaadeldavaks alaks on viis kihelkonda - Ambla, Järva-Jaani, Peetri, Koeru ja Järva-Madise.

Kuivõrd puudub Taani hindamisraamatu taoline allikas Järvamaa kohta, mis võimaldaks omaaegse halduskorralduse täpsemat uurimist, on antud juhul asustuskeskusena määratletud ümbritsevatest aladest muistiserohkuse poolest silmapaistvamad piirkonnad. Selliseid asustuskeskusi on võimalik välja tuua neljas kihelkonnas viiest.

Keskustega haakub ka halduskorralduse ning võimustruktuuride uurimine. Kuivõrd muinasaegse eliidi elupaigaks on sageli peetud linnuseid, on oluline linnuse kui keskuse roll ning suhestumine asustusega. Senises kirjanduses on esitatud oletus Järvamaa jagunemisest kolmeks muinaskihelkonnaks, samuti on - suuresti Henriku Liivimaa kroonikale tuginedes - proovitud kindlaks teha omaaegseid muinaskihelkondade keskusi.

Ilmneb, et jagunemine kolmeks kihelkonnaks on looduslikke olusid vaadeldes põhjendatud; märksa kaheldavam on aga kihelkonnakeskuste paiknemine - kroonika põhjal tehtud järeldused ei kattu kohati muististe põhjal avaneva pildiga.
\end{abstract}

Märksõnad: asustus, asustuskeskused, Järvamaa, muinasaegne haldusjaotus

\section{Sissejuhatuseks}

Eesti arheoloogias on eriti viimastel aastatel hoogustunud muinaskeskuste kindlakstegemine ja uurimine, millega erinevate projektide raames on tegeldud Põhja-Eestis, Saaremaal ja Lõuna-Eestis. Suhteliselt vähe tähelepanu on siiani pööratud Kesk-Eestile ning eriti just Eesti keskseimale maakonnale - Järvamaale. Oma keskse asendi tõttu oli Järvamaa kindlasti ümbritsevatest aladest mõjutatud, olles kas nende otsene tagamaa või kaugem ääreala. Pole ka võimatu, et võrreldes omanäolise piirkonnaga, mille suhteline eraldatus soode

http://haldjas.folklore.ee/tagused/nr28/latti.pdf 


\section{Priit Lätti}

ja metsade keskel ning viljakad põllumaad lõid eelduse suurte ja rikaste külade tekkeks. Arheoloogiliste uuringute vähesus pole võimaldanud neile küsimustele vähegi rahuldaval tasemel vastata, ent siiski lubab teadaolev informatsioon nentida, et Järvamaa puhul on tegemist ümbritsevatest aladest märgatavalt erineva piirkonnaga, mille uurimine rikastaks kindlasti pilti muistse ühiskonna korraldusest Eestis.

Muistse asustuse uurimisel on üheks peamiseks küsimuseks keskuste ja halduskorralduse problemaatika. Keskusi on võimalik eristada muististe põhjal ning keskusena on võimalik määratleda nii kirikut, linnust kui linna, aga ka lihtsalt asustuskeskust, mis eraldub ümbritsevatest aladest tihedama asustuse poolest (Lang 2002b: 9-11). Järvamaa puhul ongi võimalik asustuskeskusi välja tuua just muististe põhjal. Vakuste, võimukeskuste ja asustushierarhia uurimine antud alal on keerulisem, sest puudub Taani hindamisraama$t u$ taoline allikas Kesk-Eesti kohta.

Keskuse mõistega seostub halduskorralduse ja võimustruktuuride uurimine, mis tugineb teooriale, et keskus domineerib ümbritsevate alade üle ja mõjutab neid nii materiaalselt kui ka kultuuriliselt. Kuna linnuseid on sageli peetud muinasaegse eliidi elupaikadeks, on siinkohal oluline linnuse kui keskuse paiknemine ja tema mõjuraadius - kui kaugele see ulatus ning mis seaduspärad ja tingimused seda kujundasid.

Senises kirjanduses on esitatud oletus Järvamaa jagunemisest kolmeks muinaskihelkonnaks, samuti on proovitud välja tuua võimalikud kihelkonnakeskused. Käesolevas töös on püütud antud oletusi ja arvamusi võimalust mööda kontrollida ning üritatud välja pakkuda võimalikke alternatiive.

Niisiis keskendub alljärgnev kirjatükk kahele suuremale probleemile: vaadelda asustust Järvamaal keskuste problemaatikast lähtuvalt ja kontrollida seniseid arvamusi muinasaegse haldusjaotuse kohta. Vaatluse alla on võetud Ambla, Järva-Jaani, Järva-Peetri, Koeru ja Järva-Madise kihelkond, mis moodustavad Järvamaa südaala, ajalisteks raamideks on keskmine ja noorem rauaaeg ning keskaeg. Keskmine rauaaeg jagatakse rahvasterännuajaks (450-600) ja eelviikingiajaks (600-800), noorem rauaaeg jaguneb viikingiajaks (800-1050) ja hilisrauaajaks, mis algab viikingiaja lõpuga ning kestab umbes aastateni 1200-1250 (Lang \& Kriiska 2001: 102). Keskaja alguseks võib tinglikult pidada aastat 1250 , ehkki selleks on peetud ka võõrvallutuse lõppu (1227), ning keskaja lõpuks Liivi sõja algusaastaid 1558-1561. 


\section{Allikmaterjal ja metoodika}

Asustuse uurimiseks vaadeldavates kihelkondades on kasutatud nii arheoloogilist kui ka kartograafilist allikmaterjali. Arheoloogilisteks allikateks on linnamäed, asulakohad, aardeleiud, kivikalmed, külakalmistud, hiie-ja ohvrikohad.

Järvamaalt on teateid võrdlemisi paljudest linnamägedest, kuid valdav enamik neist on ilmselt pärimuslikku laadi ega pruugi viidata reaalsetele muististele. Selliseid oletatavaid, vaid pärimuses kajastuvaid linnamägesid on vaatlusalustes kihelkondades 15 (Lätti 2004b). Vaid ühel juhul - Ambla kihelkonnas paikneva Jäneda linnuse puhul - pole kahtlust, et tegemist on tõepoolest linnamäega. Linnuse õue pikkuseks on ligikaudu $100 \mathrm{~m}$ ning õu on olnud lõuna poolt kaitstud valli ning põhja poolt valli ja kraaviga, millest põhja poole jääb arvatav eeslinnus. Õuelt leitud kultuurkiht võimaldab linnuse dateerida I aastatuhande II poolde ja II aastatuhande algusesse (Lõugas \& Selirand 1989: 249-251).

Puudulikust uurimisseisust johtuvalt on väga vähe teada ka asulakohti (viie kihelkonna peale vaid 20), mis kõik on dateeritud rauaaja lõpuperioodidesse kuuluvateks (Lätti 2004b). Arheoloogilisi kaevamisi ei ole Järva asulakohtadel läbi viidud ja kogu teadaolev informatsioon on kogutud inspektsioonide käigus. Kuivõrd täpsem dateering on ebaselge, on antud juhul võimalik vaadelda vaid asulakohtade suhet teiste muististe - linnamägede ja kivikalmetega. Asulate materjali täpsem analüüs jääb tulevikku.

Raua- ja keskajast pärinevaid aardeleide on teada seitse (Lätti 2004b). Valdavalt on tegemist teadetega esemete leidmisest, kuid paraku on leitud esemed tihti kaduma läinud ja seetõttu tuleb ka aardeleide dateerida vaid kirjelduse järgi. Ka teadetes antud asukoha määrangud on niivõrd üldsõnalised, et tihti pole aardeleide võimalik kaardile kanda. Täpsemaid andmeid on vaid mõne aardeleiu kohta. Peetri kihelkonnast Kubjani talu maalt on teada arvatavasti keskajast pärinevate hõberõnga ja rinnarahade leidmine, Koigi mõisa maalt on leitud 150 araabia münti, mis on dateeritud 10. sajandisse (Tõnisson 1962: 197) ning 16 hõbeeset. Keskaja lõpuperioodi või uusaja algusesse on dateeritud Palu külast Märdi talust 1968. aastal leitud tinakann, mis sisaldas 16. sajandist pärinevaid münte, kolme hõbedast ning kahte merevaigust ripatsit, 27 kaurikarpi, 10 klaashelmest, krõlli ja muid esemeid. 


\section{Priit Lätti}

Koeru kihelkonnast on teada aardeleid Piibe mõisa maadelt, mille moodustasid 267 kasetorbikusse pakitud münti. Leitud müntidest oli 253 saksa, 10 anglosaksi ning üks araabia päritolu. Aardes esinenud kõige hilisemate müntide järgi on leid dateeritud 11. sajandisse kuuluvaks (Tõnisson 1962: 197). Teine, Koeru lähedalt saadud leid koosnes kolmest hõbedast hoburaudsõlest, hõbesõrmusest ja vardast ning laiade otstega hõbekaelavõrust. Kolmest hoburaudsõlest kaks on lameda kaare ja pikuti harjaga; kolmanda kaar on ümarrombilise ristlõike ja nuppotstega. Kaelavõru on punutud kaare ja plaatotstega. Arvatavasti pärineb aare 13. sajandist (Tõnisson 1962: 197).

Järva-Madise kihelkonnast on teada kaks aardeleidu. Kihelkonnakirjelduse andmetel on Kaalepi külast Sepa talu aiamaalt kündmise käigus saadud kaelavõrusid, helmeid, hoburaudsõlgi ja hõbesõrmus, mis paiknesid tuhaga täidetud augus. Kaalepi mõisa maalt on leitud ka 40 rinnaraha, kuid esemete edasine saatus on teadmata.

Ilmselt kõige tuntum Järva-Madise kihelkonnast pärit aare on 1972. aastal leitud Kihme külast Padula talu maalt ja sisaldab 11. sajandist pärinevat Saksa münti ning 325 Rootsi 16. sajandi münti. Lisaks oli aardes hõbeehteid, katkine mitmest traadist punutud ja plaatotstega kaelavõru, kaks hoburaud- ja kaks rõngassõlge, 23 rinnalehte, ligi 20 hõbekrõlli ja üks tinakrõll, klaashelmeid, mõned ripatsid, kaks purunenud tinakannu, pronksist spiraale, villase ja linase riide tükke. Leiti ka kaks ligi $35 \mathrm{~cm}$ kõrgust suurt vasknõud. Aare pärineb 16. sajandist (Lõugas \& Selirand 1989: 251).

Kivikalmeid on viiest vaatlusalusest kihelkonnast teada 76 (Lätti 2004b). Sarnaselt teiste muististega on ka kalmete dateerimine problemaatiline, kuivõrd täpseid andmeid on ainult mõne üksiku kalme kohta. Ka inspektsioonide aruanded annavad üsna laialivalguvaid dateeringuid, mistõttu tuli lähtuda vaid erinevates allikates muististe kohta antud kirjeldustest.

Kivikalmed on dateeritud nende kujust ja paiknemisest lähtuvalt. Kuivõrd pronksiajal ja eelrooma rauaajal kasutatud kivikirstkalmed paiknevad tavaliselt 5-6 kalmest koosnevates rühmades (Kriiska \& Tvauri 2002: 101, 124), siis on kõikide suuremate kalmerühmade puhul oletatud neid kivikirstkalmeteks. Mõnel juhul annab infot ka kirjeldus - mainitakse ümmargust kivist ala, mis on ümbritsetud suuremate kividega ja mille keskelt on leitud luid. 
Üldjuhul on Järvamaa puhul alust kalmet kivikirstkalmeks pidada vaid üsna vähestel juhtudel.

Teadetes kivikangrute nime all esinevad ja tavaliselt üksikult paiknevad arvatavad kalmed on muististena arvesse võetud juhul, kui on andmeid esemete või luude leidmisest või kui pärimus teab antud kohta matusepaigana. Loomulikult on selline dateerimine võrdlemisi tinglik ja oletuslik. On võimalik, et nii mitmedki kivikirstkalmeteks peetavad muistised on tegelikult märksa nooremad ja kuuluvad keskmisesse või nooremasse rauaaega.

Ka mitme tarandkalme puhul, mis muidu oma dateeringu poolest vaadeldavast ajast välja jääks, on teada nende hilisem kasutamine, mistõttu neid on antud töös siiski arvestatud. Sellekohasteks näideteks on Nurmsi tarandkalme, kuhu on maetud keskmisel rauaajal (Vassar 1972: 93), Preedi kalme, mida on kasutatud kuni 11. sajandini, samuti Tarbja Kalamehe kalme. Nooremast rauaajast pärinevaid leide on saadud ka Mustla kalmest (Lõugas \& Selirand 1989: 251-254).

Kirjeldustest lähtuvalt on dateeritud ka keskaegseid muistiseid külakalmistuid -, mida vaadeldavates kihelkondades on kokku 54 (Lätti 2004b). Külakalmistule viitab üldjuhul teade kruusa või liiva kaevamisel leitud luudest ja pärimus, mis teab antud paika matusekohana. Mõnel juhul võib aidata ka informatsioon kivide leidumisest antud kohas - kiviselt alalt leitud luud viitavad pigem rauaaegsele kalmele kui külakalmistule. Sellisel puhul eksisteerib alati ka võimalus, et leitud luud kuuluvad hoopis hilisemale järelmatusele rauaaegsesse kalmesse - tõik, mis muudab ka raua- ja keskaegsete muististe eraldamise kohati üsna oletuslikuks.

Hiie- ja ohvrikohti leidub vaadeldavates kihelkondades kokku 73 (Lätti 2004b). Nimetatud muistiseid on võimalik leida pärimuse põhjal, mis tihti on abiks ka kalmete ja külakalmistute kohta käivate andmete täpsustamisel. Kuna hiie- ja ohvrikohti dateerida on kultuurkihi puudumise tõttu äärmiselt keeruline, on nende paigutamine rauaaega ja keskaega oletuslik. Seega pole pärimuse põhjal võimalik täpsustada muististe dateeringut, vaid nende funktsiooni - teade paigast kui matusekohast aitab tihti arvatavaid kalmeid või külakalmistuid märgatavalt täpsemini liigitada.

Andmeid muististe kohta leidub 1920.-1930. aastatel Tartu Ülikooli arheoloogiatudengite koostatud kihelkonnakirjeldustes. Kirjelduse koostamisel inspekteerisid tudengid juba teadaolevaid paiku ja otsisid juurde uusi. Kuna nad muistiseid ei kaevanud, on vä- 


\section{Priit Lätti}

gagi tõenäoline, et nii mõnigi kihelkonnakirjeldustes kalmeks nimetatud objekt võib hilisemal kontrollimisel osutuda lihtsalt põllukivihunnikuks või looduslikuks künkaks. Lisaks tegelikele muististele on kihelkonnakirjeldustesse sattunud ka palju pärimuslikku infot, sest tihti polnud tudengil võimalik ajapuuduse või objekti ligipääsmatuse tõttu kõiki paiku isiklikult üle vaadata, vaid ta pidi usaldama kaudset infot. Allikmaterjaliks on ka Järvamaal hilisematel aegadel läbi viidud arheoloogiliste inspektsioonide aruanded ning muististe kohta koostatud arheoloogilised passid. ${ }^{1}$

Kolmanda suurema allikmaterjali rühma moodustasid kaardid Eesti baaskaart ja 1796. aastal Ludwig August Mellini koostatud Järvamaa kaart, millel kujutatud maastikupilt on ilmselt suhteliselt sarnane muinasaegsega, kuivõrd suuremad muutused selles toimusid seoses nõukogudeaegsete maaparandustöödega. L. A. Mellini kaardi muudavad eriti väärtuslikuks temas sisalduv toponüümiline andmestik ja kaardile kantud teed.

Muististe kaardistamisel oli abiks ka maa-ameti koduleht, mis võimaldas teada saada talude täpse paiknemise. Maa-ameti ja muinsuskaitseameti koostööna on kaardile kantud ka kaitsealused muistised, mis samuti tööd märgatavalt lihtsustas. ${ }^{2}$ Ohvri- ja hiiekohtade kaardistamisel olid kasulikud raamatus Arad veed ja salateed: Järvamaa kohapärimus (Remmel 2004) sisalduvad kaardid.

Üheks tähtsamaks abivahendiks andmestiku koondamisel oli Tartu Ülikooli arheoloogiakabinetis koostatav arheoloogilise kohainfo andmebaas, mis koondab paljudest allikatest pärinevad teated muististe kohta, tehes nii uuritavast alast ülevaate saamise märgatavalt lihtsamaks. Lisaks kihelkonnakirjeldustele, muististe passidele ja inspektsiooniaruannetele on andmebaasi koostamisel allikateks ka Eesti Keele Instituudi kohanimearhiiv, erinevates trükistes avaldatud teave muististe kohta, kodu-uurimuslikud tööd ja muuseumide leiukataloogid. Kuna muististe kohta on andmeid erinevates allikates, on andmebaasis kasutusel koodisüsteem, mis võimaldab teated omavahel siduda ja objekti kaardile kanda. Selline pärimusinfot koondav andmebaas on loodud ka Eesti Kirjandusmuuseumis ja tulevikus peaksid mõlemad andmebaasid hakkama töötama koos (Valk 2004: 135).

Käesoleva töö raames sisestati Ambla, Järva-Jaani, Järva-Peetri, Koeru ja Järva-Madise kihelkonna kohta käiv arheoloogiline ja pärimuslik informatsioon ning selle alusel oli võimalik luua muististe levikukaardid. Kuna andmed muististe paiknemise kohta on 
võrdlemisi erinevad, pole võimalik kõiki paiku täpselt lokaliseerida ja seetõttu on muistised märgitud kaardile erineva täpsusastmega. Täpselt on objekt kaardile kantud siis, kui kirjeldus või selle juures olev asukohaskeem seda võimaldas. Kui on teada talu nimi, on muistis paigutatud taluhoonete juurde, küla täpsusega paiga puhul on muistisena tähistatud küla keskpaik.

Sama täpsusskaalat on arheoloogilise kohainfo andmebaasi loomisel kasutatud ka teiste maakondade muististe puhul (Valk 2004: 137).

Asustuskeskuste ja linnuste vaatlemisel on peamiselt eeskuju võetud arheoloogide Marika Mägi, Ain Lavi ja Valter Langi uurimustest.

Marika Mägi on tegelnud Saaremaa asustusloo uurimisega ning oma raamatus ja artiklis võtab ta kokku senise uurimistöö tulemused (Mägi 2001, 2002). Asustuskeskuste kindlaksmääramiseks on M. Mägi kasutanud peamiselt arheoloogilisi muistiseid, eriti just kalmeid, mis on kantud rootsiaegsetele kaartidele (Mägi 2002). Kaartidele kantud muistised võimaldavad kindlaks teha omaaegseid asustuskeskusi ning vaadelda asustuse iseloomu ja muutumist.

Ain Lavi vaatleb Kesk-Eesti idaosa linnamägesid ja nende seost asustuse ja teiste linnustega (Lavi 2002). Nagu varasemad uurijad (Moora 1955; Jaanits \& Laul \& Lõugas \& Tõnisson 1982: 327), on ka tema jaganud linnused kahte rühma: esimesse kuuluvad intensiivse kultuurkihiga linnused, mille lähedal paikneb asula; teise moodustavad arvatavad pelgupaiklinnused, millel on nõrk kultuurkiht ja mis polnud pidevas kasutuses (Lavi 2002: 261).

Rauaaja lõpuperioodil hakkas Loode-Eestis välja kujunema linnus-asula-süsteem, mis hõlmas linnust ja selle vahetus läheduses ning otsese kontrolli all olevat asustust (Lang 1996: 367). Ehkki selliseid asustusega seostuvaid linnuseid leidub ka Kesk-Eesti idaosas, on arvatud, et need polnud suured, maakondliku tähtsusega linnused (Lavi 2002: 263).

Asustuskeskuste ja linnuste seost on vaadeldud, toetudes Valter Langi asjakohasele artiklile (Lang 2002a). Põhja-Eesti andmetele tuginedes on V. Lang käsitlenud linnusele alluvate maksustusalade - vakuste - ja linnuste seoseid, tegemaks kindlaks ühele linnusele alluvaid vakuseid ning määramaks nii kindlaks linnuse mõjupiirkonna.

Ka käesolevas töös on asustuskeskusena määratletud piirkond, mille muististe kontsentratsioon on märgatavalt suurem ümbritsevate alade omast. Keskuste kindlaksmääramisel on lähtutud eel- 


\section{Priit Lätti}

kõige kalmete paiknemisest, sest nende kohta on suhteliselt rohkem informatsiooni kui peamiselt pärimuse kaudu tuntud linnamägede kohta. Siiski on pärimuslikke linnamägesid kasutatud, vaatlemaks linnus-asula-süsteemi võimalikku olemasolu ja linnuste mõjupiirkonna ulatust. Samuti on pärimuslike linnamägede paiknemist vaadeldes proovitud kindlaks teha $n$-ö päris linnamäe eksisteerimise tõenäosus mainitud paigas - teisisõnu püütud leida vastus küsimusele, kas pärimuse kaudu teadaolev paik võinuks olla ka tegelikult linnamägi.

\section{Uurimislugu}

Järvamaa arheoloogilise uurimise alguseks võib pidada 1890. aastatel harrastusarheoloogi Jaan Jungi algatatud muististe registreerimise kampaaniat, mille eesmärgiks oli koostada kirjeldusi sisaldav nimekiri teadaolevatest muististest. Korrespondentide teadete ja oma välitööde tulemuste põhjal valmis Jungil raamatusari Muinasaja teadus eestlaste maalt, mille Põhja-Eestit ja sealhulgas ka Järvamaad puudutav osa ilmus alles pärast autori surma, aastal 1910 (Jung 1910).

Paljude inimeste kogutuna oli andmestik muististe kohta siiski võrdlemisi ebaühtlane ja erineva täpsusastmega. Seepärast algas 1921. aastal professor Aarne Michael Tallgreni (1885-1945) juhendamisel teine üle-eestiline muististe registreerimine (Lõugas \& Selirand 1989: 34). Nüüd tegid põhilise töö ära arheoloogiatudengid, kes kihelkondi uuesti üle vaadates leidsid seni juba teadaolevatele muististele lisaks ka uusi. Järvamaa kihelkonnad kirjeldati ajavahemikus 1925-1932.

18. sajandil alguse saanud huvi kasv muististe ja vanade esemete kogumise vastu viis teadusseltside rajamisele ja muuseumikogude tekkele nende juures (Jaanits \& Laul \& Lõugas \& Tõnisson 1982: 9). 1904. aastal asutati Paides Järvamaa Muinasasjade Alalhoidmise Selts, mis asus koguma esemeid ja organiseerima kaevamisi (Lõugas \& Selirand 1989: 249). Nii toimusid 1905. ja 1907. aastal Paide Muinasasjade Alalhoidmise Seltsi algatusel kaevamised Nurmsi Kirikumäel. Kuna kaevati võrdlemisi väikses mahus ning korralikku ülevaadet kalme ehitusest ja leiumaterjalist seetõttu ei saadud, uuris kalmet 1921. aastal toonane Tartu Ülikooli arheoloogiaprofessor A. M. Tallgren. 1922. aastal jätkas kaevamisi Harri 
Moora, kes pärast ühe kindla tarandimüüri ${ }^{3}$ leidmist A. M. Tallgreni Helsingist kohale kutsus. Töid jätkati peaaegu kogu kalme alal ja 1923. aastal kaevas H. Moora läbi ka seni uurimata piirkonnad (Vassar 1943).

Kõige põhjalikumalt on Nurmsi tarandkalmet uurinud Artur Vassar, kellel valmis aastatel 1934-1935 läbi viidud tööde tulemusena 1943. aastal doktoriväitekiri Nurmsi kivikalme Eestis ja tarandkalmete areng. Üsna kindlalt võib väita, et see seni käsikirjajäänud Tartu Ülikooli raamatukogus säilitatav uurimus on kõige põhjalikum käsitlus Järvamaa esiajaloost.

Lisaks Nurmsi kalmele on Järvamaal uuritud ka teisi muistiseid. Preedi Kuningamäeks nimetatud tarandkalmet kaevas 1968. aastal Tanel Moora ja Tarbja külas Kalamehe talu maal asuvat tarandkalmet uuris aastail 1958-1961 Evald Tõnisson ning aastal 1964 T. Moora. Kalamehe kalme lähedal asuv Miku talu tarandkalme on muinsushuvilised läbi kaevanud juba aastatel 1905-1907.

Järvamaal on kaevatud ka üht külakalmistut - 1960. aastal uuris antropoloog Karin Mark Räitsvere külas asuvat Vaadu Kalmamäge.

Edasine uurimistöö on piirdunud arheoloogiliste inspektsioonide läbiviimisega, mis on täiendanud juba teadaolevat pilti muististest.

Pärast eespool mainitud Artur Vassara doktoriväitekirja pole Järvamaa muististe kohta uusi andmeid suuremahuliselt enam avaldatud. Asustuse levimist vaatleb Tanel Moora oma 1966. aastal ilmunud artiklis (Moora 1966), paar artiklit on ilmunud Artur Vassara ja Evald Tõnissoni sulest (Vassar 1972; Tõnisson 1999), lühiülevaadet Järvamaa muististest pakub ka kogumik Paide rajooni ajaloo- ja kultuurimälestised (Saarist \& Tõnisson 1986), Järvamaa (ehk toonase Paide rajooni) tähtsamaid muistiseid on tutvustanud veel Vello Lõugas ja Jüri Selirand (Lõugas \& Selirand 1989). Lühike ülevaade Järvamaa muististest on ilmunud kogumikus Arad veed ja salateed: Järvamaa kohapärimus (Lätti 2004a). Järvamaa muistiseid käsitleb ka Priit Lätti 2004 aastal kaitstud bakalaureusetöö, mis asub Tartu Ülikooli arheoloogia õppetoolis (Lätti 2004b).

\section{Maastik ja looduslikud olud}

Järvamaa on maastikuliselt äärmiselt mitmekesine piirkond, mille südaalad paiknevad Pandivere kõrgustiku tihedalt asustatud ja suurte küladega lääneosas, kus asuvad Järva-Jaani ja osaliselt ka Ambla, 


\section{Priit Lätti}

Peetri ja Koeru kihelkond. Kõrgustik on rahuliku pinnamoega, milles valdavaks on lainjad moreentasandikud. Vaid kõrgustiku äärealadel leidub väikevoori ja vallseljakuid (Varep 1972: 13-14).

Tänu karstinähtusele puuduvad Pandivere kõrgustikul vooluveed, mis valguvad sügavale maapinda. Selline jõgede ja ojadeta ala ulatub Roosna-Allikult maakonna idapiirini ning Tapa lähedalt Prandi, Koigi, Udeva ja Norra külani. Maapinda valgunud veed ilmuvad uuesti nähtavale kõrgustiku äärealadel, kus asuvad Jootma, Roosna-Alliku, Kuru, Vodja, Esna, Prandi, Norra ja Oostriku allikad (Varep 1972: 16).

Suurt osa Pandivere kõrgustikust katavad parasniisked leostunud ja leetjad kamarmulad, mis on viljakaimad Eestis (Varep 1972: 16). Seetõttu on suur osa Pandivere kõrgustiku aladest üles haritud ning metsa on alles vaid õhema mullakihiga piirkondades, mis pole põllumajanduseks nii sobivad. Metsi leidub ka külade äärealadel ja need tähistavad niimoodi asustusüksuste piire.

Viljakas ja seetõttu samuti tihedalt asustatud ja üles haritud ala on ka Pandivere kõrgustiku edelaosas paiknev Türi voorestik.

Sarnaselt teistegi põllumajanduseks sobiva aladega, on ka Türi voorestiku maastikupilti suuresti muutnud maaparandustööd, mille käigus on õgvendatud jõgesid ja kaevatud kraave (Varep 1972: 27).

Pandivere kõrgustikuga looduslikult üsna sarnane on ka KeskEesti moreentasandik, mis halduslikult jääb endise Põhja-Viljandimaa alale. Ajaloolisest Järvamaast ulatub Kesk-Eesti moreentasandikule Koigi ümbrus Peetri kihelkonnas (Tõnisson 1999: 7). Ka KeskEesti moreentasandiku puhul on tegemist suurte küladega põlise asustuspiirkonnaga (Varep 1972: 31). Maastikuliselt on tegemist kohati soostunud lainja moreentasandikuga, kus pole suuri jõgesid ega järvi, sest oletatavasti on ka Kesk-Eesti moreentasandiku puhul tegemist karstialaga. Esineb vaid allikaid, millest saavad alguse Navesti jõgi ja tema lisajõgi Räpu oja. Järvi on vaid üks - Jalametsa soos asuv samanimeline veekogu (Varep 1972: 30).

Kõrgustikust lääne ja loode pool asub metsa- ja soorikas Kõrvemaa, mis järsult erineb üles haritud Pandivere aladest. Et põlluharimiseks sobivat mulda on Kõrvemaal vähe ning ala pole asustuseks eriti soodne, on see ilmselt olnud teatavaks piiriks Järvamaa ja naaberalade vahel. ${ }^{4}$

Kõrvemaa omamoodi jätkuks lõuna ja edela suunas on valdavalt soode ja metsaga kaetud ning hõredalt asustatud Pärnu madalik (Tõnisson 1999: 7). 
Koeru kihelkonna alal Pandivere kõrgustikust lõunas asub metsade, soode ja niitudega kaetud ning seetõttu põllumajanduseks üsna ebasobiv Endla nõgu (Varep 1972: 29). Antud ala vähene asustus on koondunud peamiselt nõo äärealadel asuvatele vooretaolistele kõrgendikele, näiteks Merja ja Valila seljakutele (Tõnisson 1999: 7).

\section{Asustuskeskused ja linnused}

\section{Asustuskeskused}

Muististe põhjal on asustuskeskusi võimalik eristada neljas kihelkonnas viiest. Ambla kihelkonnas võib asustuskeskusena välja tuua Jäneda-Raudla ümbruse, kus asub linnus, asulakoht ning kalmeid ja külakalmistuid. Teise suurema keskuse moodustab KäraveteKukevere külade ümbrus asulakoha, kalmete, külakalmistu ja hiie ning ohvrikohtadega. Käravete-Kukevere piirkonnaga haakub ehk ka Raka ja Prümli külade ümbruskond sealsete - valdavalt keskaegsete - muistisega.

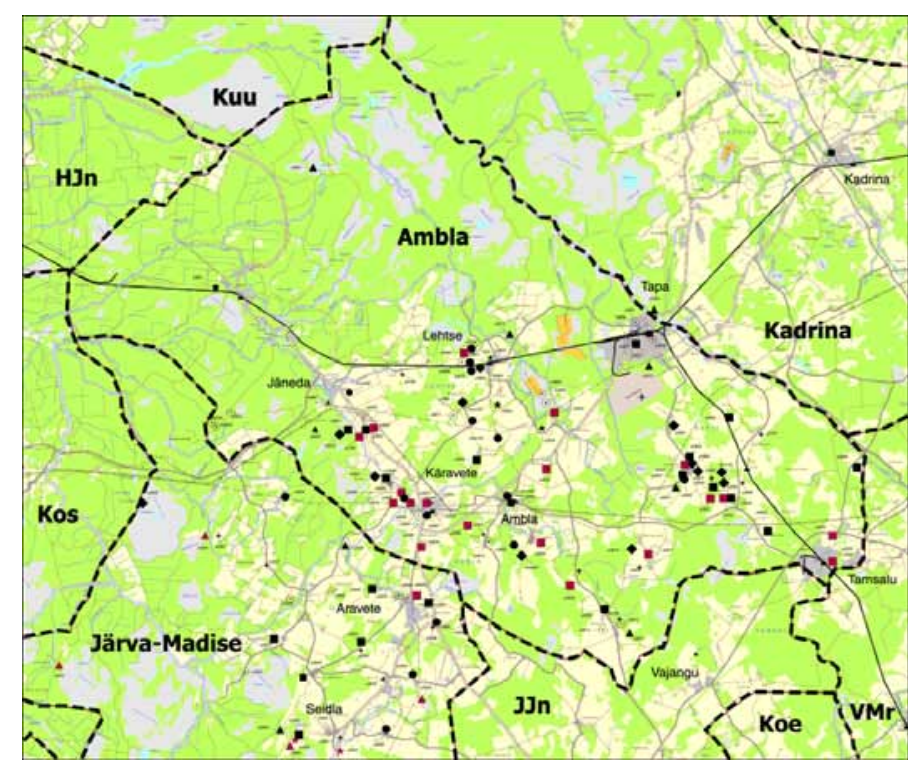

Ambla kihelkond 


\section{Priit Lätti}

Mõnevõrra eemale jäävad Roosna ning Reinevere külad. Roosna külast on teada rauaaegne kalme, samuti keskaegne külakalmistu. Reinevere külast on teada kivikalme ja hiiekoht.

Suur muististerikas piirkond paikneb Lehtse-Kuruküla-Pruuna kandis, kust on teada asulakoht, paar rauaaegset kalmet ja mitmeid keskaegseid muistiseid. Ilmselt üsna asustuskeskuse piiri lähedale jäävad Rägavere ja Linnape küla, kust on teada hiie-ja ohvrikohti ning külakalmistu. Käravete-Kukevere ja Lehtse piirkonna vaheline ala on silmapaistvalt muististevaene.

Eraldi piirkonnana saab välja tuua Karkuse-Nõmmküla ala. Antud ala lähedal paiknevad ka ilmselt eelrooma rauaajast või koguni pronksiajast pärinevad Moe kivikirstkalmed, mis on praegustel andmetel Järvamaa vanimad kalmed.

Valdavalt on mainitud piirkonnas teada keskaega kuuluvaid muistiseid - külakalmistuid ja hiiekohti -, kuid on ka kaks rauaaegset kalmet. Karkuse-Nõmmküla piirkonnaga seostub ka SääseUudeküla kant kahe rauaaegse kalme ja ühe külakalmistuga, samuti Savalduma küla ühe külakalmistuga.

Järva-Jaani kihelkonnas on valdav enamik rauaaegseid muistiseid koondunud küladesse ümber praeguse Järva-Jaani aleviku, asudes sellest keskmiselt 5-11 km kaugusel. Vaid hiiekoha ja kiviristiga Kuie küla jääb sellest ringist kaugemale. Mainitud küladest

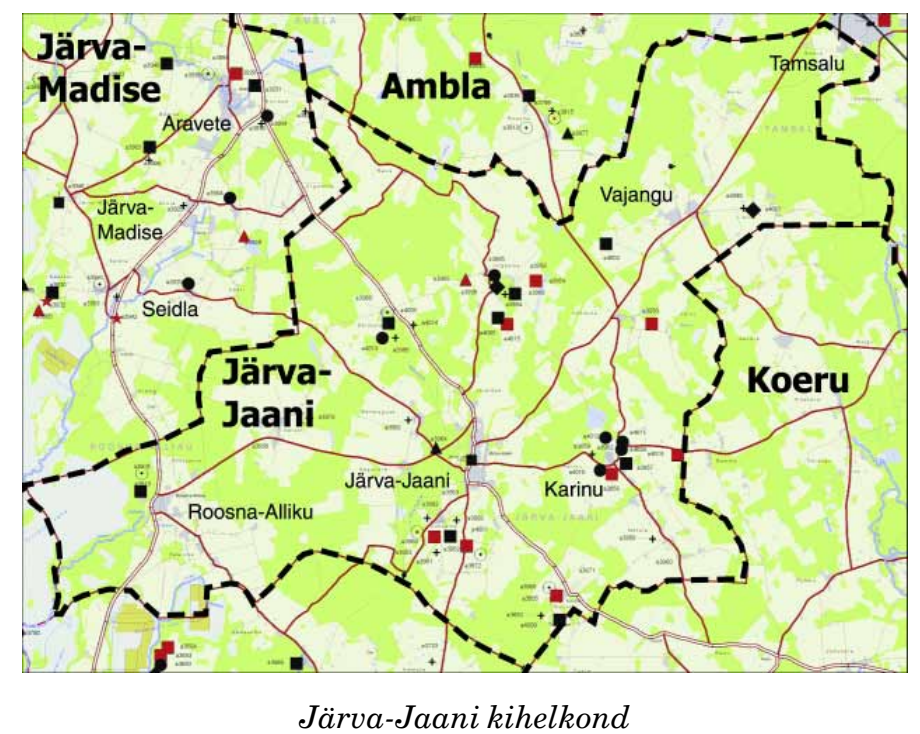


mõnevõrra eemale jääb ka Valasti küla, kust on teada asulakoht. Muistiserikkad külad on Karinu, Kuusna, Kuksema ja Jalgsema. Jalgsema külaga seostub ka teade linnusest. Mainitud külades välja arvatud Valastis - leidub ka keskaegseid muistiseid.

Peetri kihelkonnas saab välja tuua kuus asustuskeskust. Esimese moodustavad Väike-Kareda ja Suurpalu külad, teise VäikeKareda küla piirkond, millega võiks haakuda ka Müüsleri küla. Omaette piirkonna, kus domineerivad valdavalt keskaegsed muistised, moodustab Suur-Kareda küla, millega haakub ka Ammuta. Eelnimetatutest mõnevõrra eemal asuvad Nurmsi, Koordi ja Koigi piirkonnad kalmete ja asulakohtadega.

Laiemas mastaabis võiks asustuse Peetri kihelkonnas jagada kaheks - Väike-Kareda, Nurmsi ja Koigi piirkond ning Koordi, Suur-

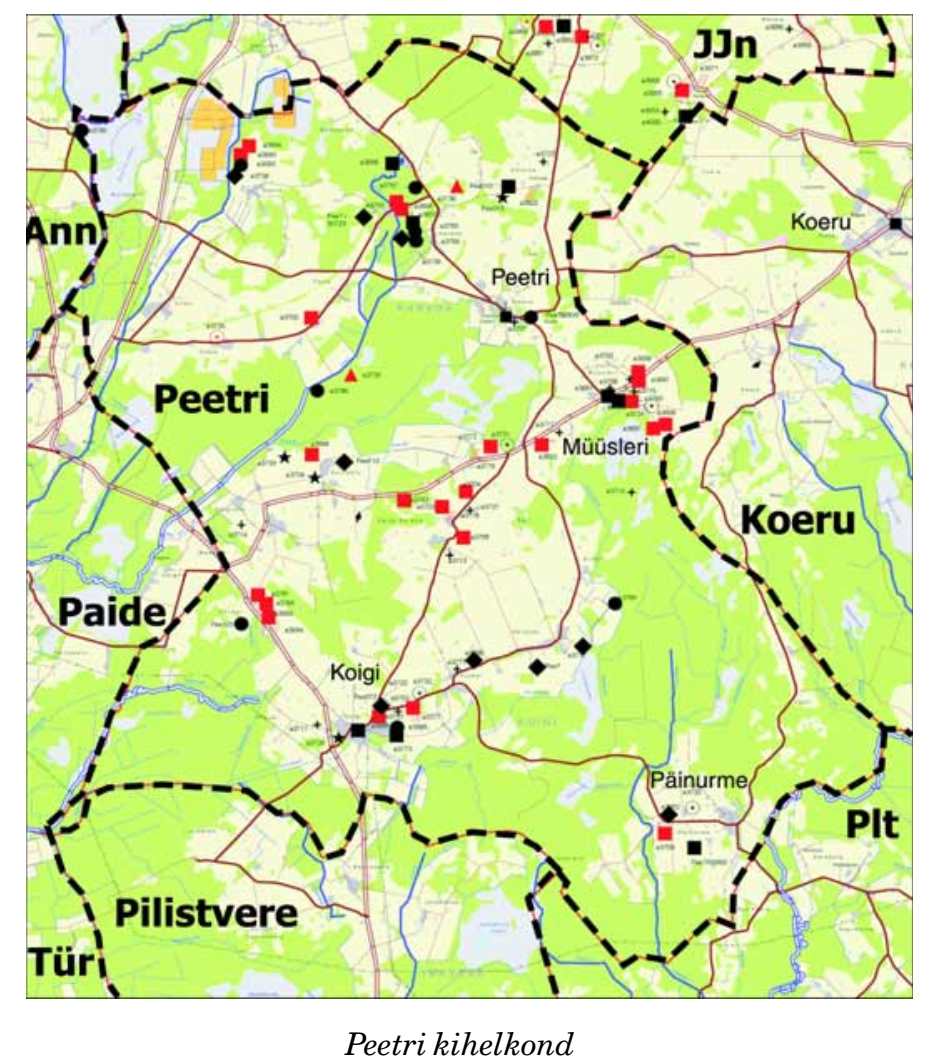




\section{Priit Lätti}

Kareda ja Müüsleri piirkond. Piiriks nende vahel võiks olla Köisi soo.

Vaadeldes eriaegsete muististe paiknemist kaardil võib oletada teatavat asustusnihet rauaaja lõpuperioodil. Rauaaegsed muistised paiknevad peamiselt Väike-Kareda piirkonnas, keskaegsed muistised on aga koondunud Suur-Kareda lähedale. See tõik võiks seada kahtluse alla väite, et Väike-Kareda on noorem kui Suur-Kareda (ka: Esna) (Tõnisson 1999: 15). Suur-Karedat pidas Kareda külast rääkides arvatavasti silmas ka Läti Henrik (Tõnisson 1999: 15). Avanev pilt võiks viidata võimalusele, et keskaja algul sai tähtsamaks Suur-Kareda küla, mis ilmselt asus piirkonda läbivate teede suhtes soodsamal positsioonil. Samale võimalusele viitavad ka Artur Vassar ja Evald Tõnisson (Vassar 1972: 98; Tõnisson 1999: 15). Väiteks on alust andnud Henriku Liivimaa kroonikas mainitud vallutajate ja kohalike elanike kohtumised Kareda külas (HCL XX: 6), mis viisid-

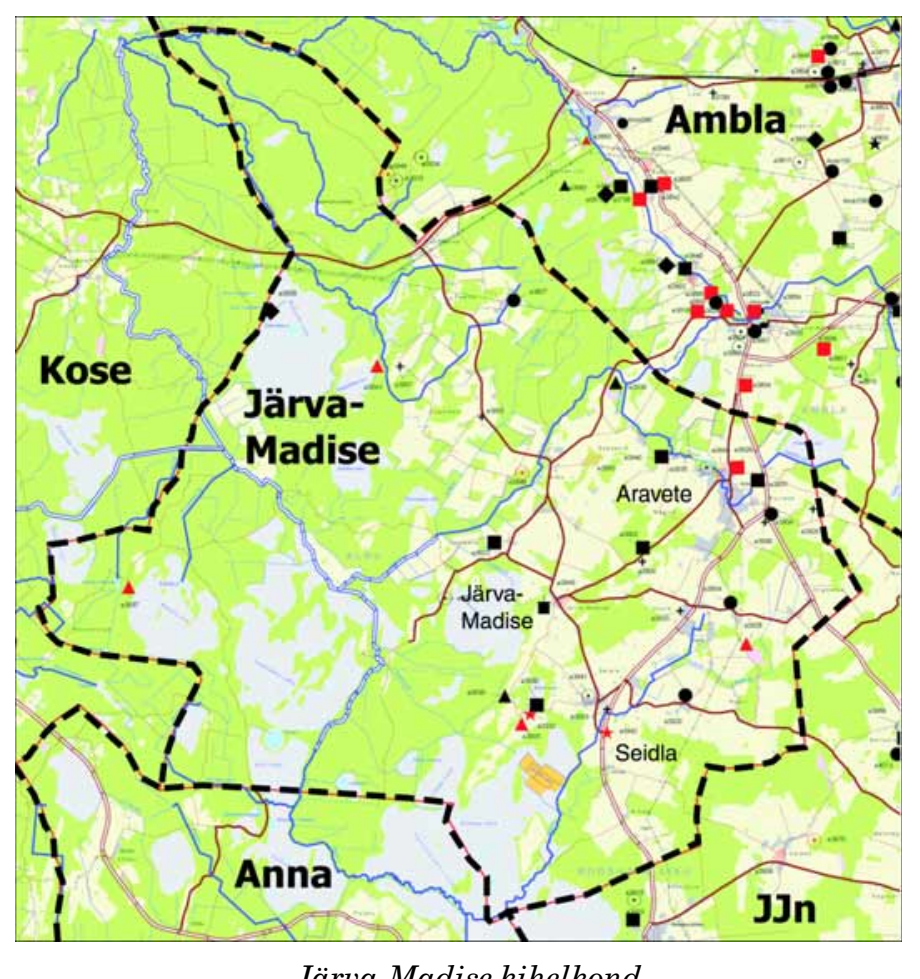

Järva-Madise kihelkond 
ki järelduseni, et Kareda küla näol oli tegemist omaaegse Järvamaa keskusega, kuhu jooksid kokku teed mitmelt poolt (Vassar 1972: 98).

Järva-Madise kihelkonnas saab välja tuua vaid ühe asustuskeskuse, mille piires asub enamik kihelkonnas teadaolevaid muistiseid. Rauaaegseid muistiseid on võrdlemisi vähe - vaid üks kalme ja asulakohad Aravetel, Sääskülas ja Järva-Madise alevikus. Kõige

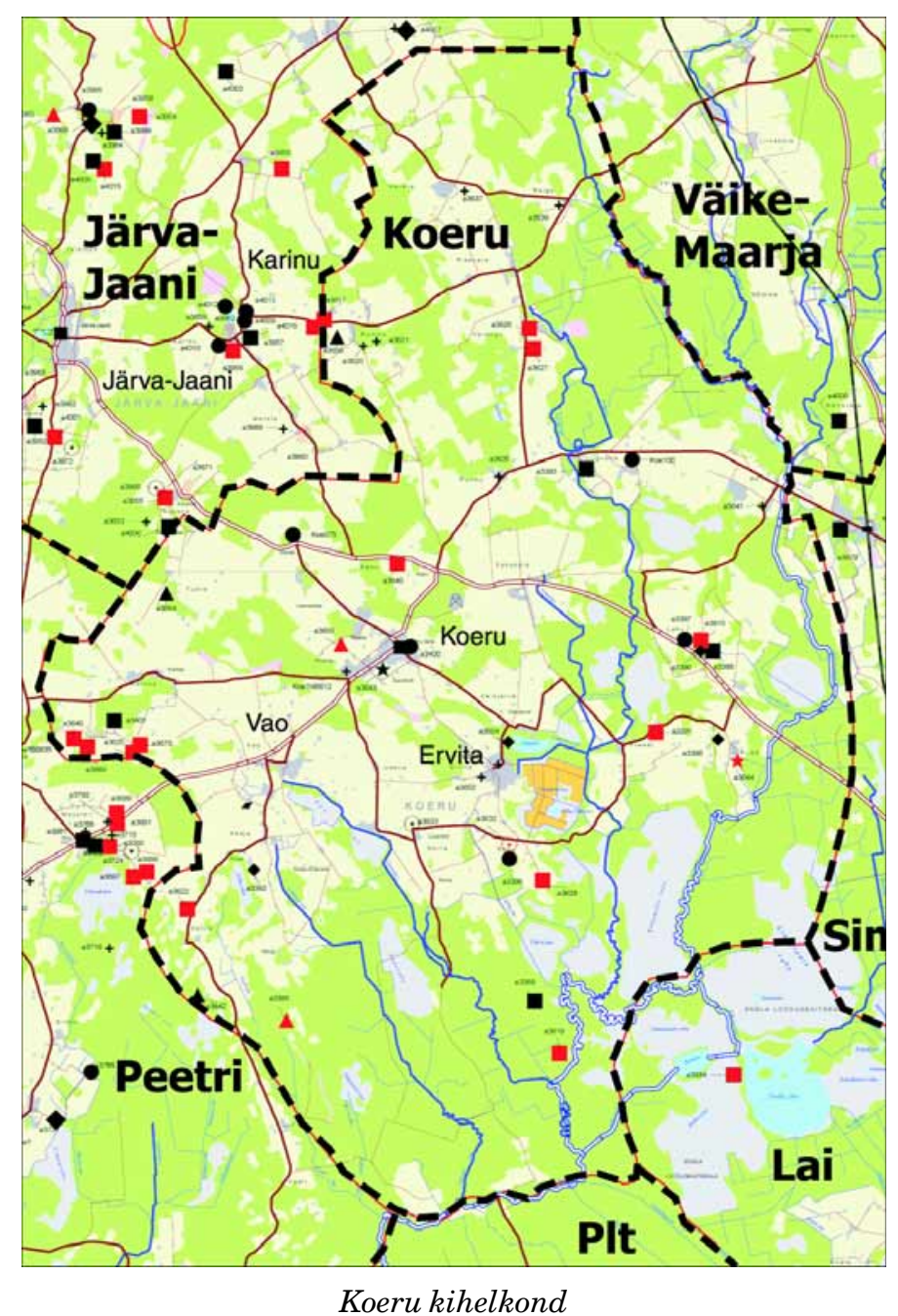




\section{Priit Lätti}

enam muistiseid paikneb Aravetel, kus lisaks rauaaegsele kalmele on teada ka kaks külakalmistut ja ohvrikoht.

Asustuskeskuse piir jookseb arvatavasti Kaalepi, Vetepere ja Sääsküla küla tagant, kust algavad asustamata ja soised alad. Üksikuid muistiseid paikneb ka asustuskeskusest eemal, sealhulgas üks arvatav linnamägi ja ohvrikoht.

Tinglikult võiks keskusena välja tuua ehk ka Kaalepi küla, kus asub arvatav linnamägi ning kust on teada ka külakalmistu ja aardeleid.

Ülalvaadeldud kihelkondadest mõneti erinev on Koeru, kus pole võimalik asustuskeskusi eristada. Muistised, nende hulgas suhteliselt palju rauaaegseid, paiknevad üle kihelkonna laiali ega moodusta kompaktset ala. Kõige enam rauaaegseid muistiseid paikneb Tammiku külas kihelkonna piiri ääres ja on arvatavasti seotud Järva-Jaani kihelkonna Müüsleri piirkonnaga.

\section{Linnused, nende roll ja mõjuraadius}

Järgnevalt vaatlen võimalikke linnuseid ja nende suhestumist ülejäänud asustusega. Üheks teemaks on linnuste mõjuraadiuse vaatlemine. Kui käsitleda linnust kaitserajatisena, on oluline sinna varjule pääsemise kiirus, mistõttu ei saanud linnuse tagamaa olla kuigi suur. Läänemaa linnusepiirkondi analüüsinud Mati Mandeli arvates ei olnud linnuse otsene mõjuala palju üle 3 kilomeetri (Mandel 2004: 197). See kehtib eelkõige linnuse kui kaitserajatise puhul. Kuna aga linnuseid on peetud ka majanduslikeks keskusteks (Tvauri 2002: 292), võis nende asustuslik tagamaa olla märgatavalt suurem, sest keskusesse pääsemise kiirus antud juhul enam rolli ei mänginud. Pealegi, nagu nendib ka M. Mandel, ei leidnud linnuses kindlasti mitte kaitset kogu linnusele alluva piirkonna elanikkond (Mandel 2004: 197), mis muudab ka linnuse kui kaitserajatise mõjuraadiuse määramise äärmiselt keeruliseks.

M. Mandeli poolt välja toodud mõjuraadiust - ligi $3 \mathrm{~km}$ - Järvamaa puhul rakendada ei saa, sest Järvamaa linnused jäävad lähimatest muististest mõnevõrra kaugemale ja külade seost linnustega on märgatavalt keerulisem kindlaks teha.

Järvamaa ainus kindel linnamägi - Ambla kihelkonnas paiknev Jäneda linnus - on võrdlemisi lähedal kõige tihedamini asustatud piirkonnale. Linnusele lähimate muististeni on ligikaudu $4 \mathrm{~km}$, 
Kukevere-Käravete asustuskeskuse tuumik jääb mõnevõrra kaugemale, kuuludes arvatavasti siiski linnuse mõjupiirkonda, mis sellisel juhul oleks umbes $15 \mathrm{~km}$ ulatusega. Antud raadiusega ring haarab ka Lehtse piirkonna, kuid jätab välja teised kihelkonna tihedamalt asustatud alad.

Kui silmas pidada, et linnus võis olla pigem majanduslik kui sõjaline keskus, võib selle mõjuraadiuse arvestamisel võtta aluseks ka päevateekonna pikkuse. Päevateekond pikkusega $30 \mathrm{~km}$ (Einer 1988: 52) katab peaaegu terve Ambla kihelkonna, välja jääb vaid linnusest 35-40 km kaugusel paiknev Karkuse-Nõmmküla piirkond.

Kui proovida määrata Jäneda linnuse mõjuala looduslikest tingimustest lähtuvalt, kujuneks selleks umbes $20-24$ km, sest Prümli ja Jõgisoo küla tagant algab väheste teedega soine ala, mis moodustab piiri. Ka sellisel juhul ei kuuluks Jäneda linnuse kontrollitavasse alasse Karkuse-Nõmmküla piirkond ega Koigi ja Roosna küla.

Kuna Jäneda linnuse õuelt on avastatud püsiasustusele viitav kultuurkiht (Tõnisson 1999: 15), võib oletada, et tegemist oli n-ö korralikult funktsioneeriva keskusega. Linnuse rollist sõjalise rajatisena pole aga midagi teada, sest Henrik Liivimaa kroonikas seda ei maini ja pole ka andmeid piiramiste kohta vallutussõdade ajal 13. sajandil (Tõnisson 1999: 15).

Järva-Jaani kihelkonnast on teada üks arvatav linnus - Jalgsema külas paiknev Siimumägi -, mis seostub kahe samas külas paikneva rauaaegse kalme ja asulakohaga. Teised kihelkonnas paiknevad rauaaegsed muistised jäävad märgatavalt kaugemale. Läheduse tõttu rauaaegsete muististega võiks Siimumäe linnust reaalset eksisteerinud keskuseks pidada, ehkki andmeid kaitserajatistest ega kultuurkihi olemasolust ei ole.

Kui antud linnamäe puhul on tegemist majandusliku keskusega, võiks tema tagamaa katta kogu Järva-Jaani kihelkonna, sest kõik kihelkonnast teadaolevad muistised jäävad umbes $20 \mathrm{~km}$ raadiusesse. Kuivõrd Järva-Jaani kihelkonna puhul on tegemist olnud ülesharitud alaga, ei piira linnuse mõjuraadiust ka looduslikud takistused.

Peetri kihelkonnas asuv Villismägi jääb rauaaegsetest muististest samuti umbes $3 \mathrm{~km}$ kaugusele, olles seotud Suur-Kareda küla piirkonnaga. Linnuse kontrolli alla võinuks kuuluda Suur-Kareda ja Ammuta piirkonna asustus, mis annab mõjuala suuruseks umbes $5 \mathrm{~km}$ raadiusega ringi. Kuna pole otsest põhjust Villismäge sõjali- 


\section{Priit Lätti}

seks rajatiseks pidada, on tõenäolisem, et seegi rahvapärimusest tuntud paik oli samuti pigem majanduslik keskus.

Päevateekonda mõjuraadiuse arvestamisel aluseks võtta on Peetri kihelkonnas mõneti keeruline, sest ala ümbritsevad looduslikud piirid. Mäletatavasti asub suuremate asustatud piirkondade (Väike-Kareda, Koigi, Nurmsi ja Koordi, Suur-Kareda, Müüsleri) vahel Köisi soo, kust läbipääs paiknes ilmselt Müüsleri küla juures. Seega pole $30 \mathrm{~km}$ päevateekonna pikkusena kindlasti tõenäoline. Nii võiski Villismäe mõjuraadius ulatuda Müüsleri ja Koordi külani, mõjuala piiriks võisid olla Köisi soo ja asustatud piirkondade vahelised metsased alad.

Teine Peetri kihelkonnas asuv arvatav linnamägi paikneb Palu külas, jäädes lähimatest muististest umbes $4-5 \mathrm{~km}$ kaugusele. Kuivõrd linnamäelt pole teada kaitserajatisi ega kultuurkihti ja temaga seostub pelgupaiga pärimus, pole ilmselt eriti tõenäoline, et tegemist oleks olnud n-ö päris linnusega.

Koeru kihelkonnast on teada kaks võimalikku linnust. Neist esimene paikneb praeguse Koeru aleviku lähedal Linnamäe talu maal. Sarnaselt teiste arvatavate linnustega pole ka selle kohta teada kaitseehitiste ega kultuurkihi olemasolu; ainsa linnusega seostuda võiva muistisena tuleb kõne alla Külaaseme külas asuv rauaaegne kalme, mis jääb linnusest umbes $4-5 \mathrm{~km}$ kaugusele.

Merja linnamägi jääb eelmainitutega võrreldes asustatud piirkondadest märgatavalt kaugemale ning ka sellel puuduvad teadaolevalt kaitserajatised. Lähedase asustuse puudumine ei anna alust pidada paika ka majanduslikuks keskuseks, pigem on Merja puhul tegemist pelgupaigaga.

Järva-Madise kihelkonna alal on teada kolm võimalikku rauaaegset linnust. Neist esimene paikneb Mõnuvere külas ega seostu rauaaegsete muististega. Suure tõenäosusega on tegemist pärimuspaigaga, millel linnuse või majandusliku keskuse funktsiooni pole olnud.

Ageri külas asuv Suurmäeks kutsutud linnamägi seostub vaid kahe ohvrikohaga, kalmeid ega asulakohti linnuse läheduses ei paikne. Kuivõrd pole ka andmeid kaitserajatiste ega kultuurkihi olemasolu kohta nimetatud paigas, pole alust Suurmäge linnuseks pidada.

Kihelkonna kolmas teadaolev linnamägi asub Kaalepi küla maadel Kaalepi ja Kihme aardeleidude lähedal. Need on ka ainsad rauaaega dateeritud leiud linnuse lähedal, oletatav linnus Ageri külas jääb ligikaudu 12-13 km ja Aravetel asuv kalme umbes $17 \mathrm{~km}$ kaugusele. Sarnaselt eelkirjeldatud arvatavate linnamägedega pole ka 
Kaalepi linnamäelt teada kindlustusi ega kultuurkihti, seega pole alust pidada linnamäge sõjaliseks keskuseks.

Vaadeldes Järvamaa linnuseid, ilmneb, et valdav enamik neist on teada vaid tänu pärimusele ja arheoloogiliselt pole neid uuritud. Seetõttu on ka väga raske teha mingeid järeldusi nende funktsiooni kohta.

Kuna kaitserajatised on teada vaid ühelt linnuselt (Jänedalt) ning teised linnamäed on väiksemad ja teadaolevalt kindlustamata, võib järeldada, et ilmselt ei tuntud linnuseid kaitserajatistena. Pärimuses linnamägedena kajastuvad paigad võivad viidata pigem kohaliku tähtsusega majanduslikule keskusele, suurtalule, milles elas mingis piirkonnas teatavat positsiooni omav ülik. Antud oletust saab kontrollida vaid arheoloogiliste uuringutega, mille käigus selgub kultuurkihi olemasolu või puudumine linnustel. On ilmne, et omaaegsest jõukast keskusest peab olema säilinud intensiivne kultuurkiht.

Niisiis võiks olukord Järvamaal olla ehk mõnevõrra sarnane Kesk-Eesti idaosale, kus asuvad linnused olid samuti arvatavasti pigem kohaliku tähtsusega keskused (Lavi 2002: 263).

Selliste keskustena võiksid kõne alla tulla Jäneda linnus, Jalgsema küla lähedal paiknev linnamägi, Villismägi ning ehk ka Kaalepi linnamägi. Linnus-asula-süsteemi eksisteerimist Järvamaal tuvastada pole praeguse uurimisseisu juures võimalik, sest väga suure tõenäosusega pole kõiki asulakohti veel leitud. On ka võimalik, et linnus-asula süsteem Järvamaal välja ei kujunenudki, sest tihedal koondumisel keskuse ümber on eelkõige kaitsefunktsioon (Lavi 2002: 264). Maakonna asend soode ja metsade keskel võis muuta aga linnused kaitserajatisena ülearuseks (Vassar 1972: 100). Kuivõrd linnuseid kaitserajatistena ei tuntud, ei koondunud asustus linnuste vahetusse lähedusse ning linnus-asula-süsteemi ei tekkinudki.

Linnuste kui kaitseotstarbeliste rajatiste puudumisele peaksid viitama ka hulgalised pärimusteated pelgupaikadest, kuhu ohu korral põgeneti, samuti tõik, et Henrik ei teata ühegi linnuse piiramisest sõjakäikudel Järvasse.

Henriku teatel oli Järvamaa puhul tegemist rikka maakonnaga (HCL XV: 7), millest lähtudes tundub avanev pilt olevat siiski mõnevõrra kummaline. Rikkus peaks ligi tõmbama vaenlasi, seega oleks loogiline eeldada linnuste olemasolu, kus ülikkond oma varaga kaitset võiks leida - kaitsmata suurtalud või majanduslikud keskused on liiga lihtsalt vallutatavad. 


\section{Priit Lätti}

Pole muidugi võimatu, et linnamägedel olidki mingid kaitseehitised, kuid nende jäänuseid pole maapinnal nähtavatena säilinud ning need võivad olla avastatavad ainult väljakaevamiste abil. Kui kaitseehitised ka eksisteerisid, olid need ilmselt suhteliselt nõrgad, nii et nende vallutamine ei nõudnud tõsisemat piiramist.

Järvamaa teadaolevaid linnamägesid vaadeldes jääb mulje, et nende puhul polnud tegemist mitte niivõrd kaitseotstarbeliste paikadega, vaid pigem võisid nad olla teatava piirkonna majanduslikeks keskusteks, kus elas antud piirkonda kontrolliv ülik. Vaatamata sellele, et kaitseehitisi pole teada, ei saa välistada ka võimalust, et vähemalt mõnda linnust võidi ohu korral ka varjupaigana kasutada.

\section{Haldusjaotus ja muinaskihelkondade võimalikud keskused}

Järvamaa esiajalugu ja muistiseid käsitlevates kirjutistes on mainitud Järva jagunemist kolmeks kihelkonnaks, millest nimeliselt on teada vaid üks - Loppegunde keskusega Reinevere ehk Koigi külas. Teine muinaskihelkond, mille keskus asus Kareda külas, kattis hilisemate Peetri, Anna ja Paide kihelkonna alasid, kolmas kihelkond keskusega Keitises (hilisem Järva-Jaani) asus Järva-Jaani ja Koeru aladel (Jaanits \& Laul \& Lõugas \& Tõnisson 1982: 403). ${ }^{5}$

Ehkki Järvamaad käsitlevates artiklites (Vassar 1972; Tõnisson 1999) pole mainitud põhjusi, mis tingisid maakonna jagamise kolmeks, võivad sellise jaotuse aluseks olla looduslikud olud. Teatavasti moodustus üks kihelkond Amblast ja Järva-Madisest. Asustus Järva-Madise kihelkonnas jääb selle Ambla-poolsele servale ning on võrdlemisi tõenäoline, et nimetatud kihelkonnad võisid kokku kuuluda. Ambla kihelkonna muistiserikkast Käravete piirkonnast on Järva-Madise kihelkonna Sääskülani umbes 8 km. Kahe kihelkonna vahel pole ka suuremaid looduslikke tõkkeid - ei metsi ega soid. Teisest naaberkihelkonnast - Järva-Jaanist - jääb Järva-Madise asustus märgatavalt kaugemale ning vahepealsed alad on muistisetühjad ja kaetud valdavalt metsaga.

Teise piirkonnana on nimetatud Järva-Jaanit ja Koerut. Nimetatud kihelkondade piiridel paiknevad mitmed muistised, mille vahemaa on suhteliselt väike. Ehkki kihelkondade vahel asuvad võrdlemisi suured metsad, kust viivad läbi vaid mõned teed, tundub Koeru Järva-Jaaniga looduslikult siiski tihedamalt seotud olevat kui 
naabruses asuva Peetri kihelkonnaga. Viimasest eraldavad Koerut lisaks metsadele ka soised alad. Sidet Peetriga võiksid aga kajastada Müüsleri ja Kalitsa külades paiknevad muistised.

Ka kolmanda muinaskihelkonna alale jäävad kihelkonnad-Paide, Anna ning Peetri - võiksid looduslikult seotud olla, sest neid ei eralda metsad ega sood. Et tegemist oli juba muinasaegse maakonna piirialadega (Tõnisson 1999: 5), pole ilmselt tõenäoline, et Peetri kihelkonna ja maakonna piiri vahel võinuks olla veel mõni väiksem kihelkond.

Niisiis tundub Järva jagunemine kolmeks muinaskihelkonnaks looduslikest tingimustest lähtuvalt olevat põhjendatud. Hoopis huvitavam on lugu võimalike kihelkonnakeskustega.

Kareda küla puhul on keskusena määratlemist põhjendatud kalmete suure hulgaga, mis viitab rauaaegsele asustusele, kuid kahe ülejäänud keskuse - Reinevere ja Kettise - kohta põhjendust ei ole. Koguteosest Eesti esiajalugu võib siiski välja lugeda, et arvamus põhineb Henriku Liivimaa kroonikal, kus korduvalt mainitakse Kareda küla ning kohalike ja vallutajate kohtumisi seal (Jaanits \& Laul \& Lõugas \& Tõnisson 1982: 403). Vaadeldes muististe rohkust Kareda piirkonnas, võib sellega nõusse jääda - kindlasti oli antud piirkonna puhul tegemist juba rauaajal eksisteerinud suure keskusega.

Reinevere ehk Koigi küla Loppegunde kihelkonna keskusena on aga paraku märksa kahtlasem. Ehkki külas on täheldatav rauaaegne põhi (teada on üks rauaaegne kalme) ning on teada ka hiiekoht, on kontrast teiste aladega ikkagi väga suur. Väidetav keskus asub Ambla kihelkonna piiri lähedal suhteliselt suurte soisteja asustamata alade keskel, paiknedes nii pigem kihelkonna ääremaal kui omades keskset positsiooni. Paiknemise ja ka muististe hulga poolest võiks Loppegunde keskusena kõne alla tulla hoopis Käravete piirkond.

Tõsi, Reinevere küla on ainus, mida Henrik on antud piirkonnas maininud, kuid siinkirjutaja arvates ei pruugi see fakt olla kindlaks tõendiks keskuse kohta.

Kroonikast selgub, et Reinevere külasse jõudes lasksid ristijad kohalikud elanikud sinna kokku tulla (HCL XXIV: 5). Siinkohal tuleb märkida, et ristijate käitumine Reineveres erines nende tavalisest praktikast - Nurmekunde kihelkonda ristides tegid nad peatuse igas suuremas külas, Reineveres aga lasksid kohalikud enda juurde kutsuda (HCL XXIV: 5). Mis sellise käitumise põhjustas, pole teada. Ehk soov oma võistlejaid taanlasi ennetada?

Ometi annab see tõik alust kaheks oletuseks: kas Reinevere puhul oli tõesti tegemist keskusega ja ristijad ei pidanud seetõttu teistesse 


\section{Priit Lätti}

küladesse minekut vajalikuks või polnud ristijatele oluline minna kindlasti keskusse? Piisas külast, mida kohalikud teadsid ja kuhu nad oskasid kokku tulla. Vaadeldes Reinevere küla paiknemist ja teadaolevate muististe vähesust, tundub praegu tõenäolisem teine oletus.

Lisaks Reinevere külale on Henriku Liivimaa kroonikas mainitud ka Järva-Jaani kihelkonnas asuvat Jalgsema küla ja tõika, et taanlased olevat kohalikke just seal ristinud (HCL XXIV: 5). Jalgsema on muististe põhjal rauaaegse põhjaga küla ning sellega seostub ka teade linnamäest. Seega on ristimise läbiviimine Jalgsemal põhjendatud - see tundub olevat piirkonna tähtsamaid keskusi.

Keitise ehk hilisema Järva-Jaaniga, mida on peetud keskuseks (Jaanits \& Laul \& Lõugas \& Tõnisson 1982: 403), rauaaegseid muistised ei haaku. Otsest põhjust nimetatud küla keskuseks pidada ei saa välja lugeda ka Henriku Liivimaa kroonikast, kus seda on mainitud lihtsalt ühe ristimispaigana (HCL XXIV: 5). Keitise kui võimaliku keskuse poolt räägib aga tõik, et taanlased ehitasid sinna hiljem kiriku. Ehkki kroonik mainib, et taanlased teinud seda mitmetes juba sakslaste poolt ristitud külades, pidid kirikule koha valimisel rolli mängima muudki aspektid.

Nagu mainitud, pole Järva-Jaani alevikust (ehk kunagisest Keitisest) teada rauaaegseid muistiseid. Lähim rauaaegse põhjaga küla asub $2 \mathrm{~km}$ eemal Kuksemal, mis võis olla paigaks, kus ristijad pidama jäid ja mida Henrik Keitiseks nimetas. Kui käsitleda Kuksemat võimaliku keskusena, on kiriku asukoht põhjendatud, sest ehkki kirikut ei pruugitud ehitada otse keskusesse, oli viimase lähedus kindlasti oluline. Keskuses või selle lähedal ristuvad piirkonna teistest küladest ja ka teistest kihelkondadest tulevad teed ning keskus on kõige tihedamalt asustatud paik.

Niisiis on antud muinaskihelkonna keskust kindlaks teha kohati problemaatilisem kui ülejäänud kahel juhul. Ühelt poolt muististe esinemine kroonikas mainitud ja teadaolevalt ristimispaigaks olnud külas, teiselt poolt aga paiga valik kirikule, mis arvatavasti ehitati keskusele üsna lähedale.

\section{Lõpetuseks}

Käesoleva kirjatöö puhul on tegemist katsega heita valgust muistsele asustuspildile ja halduskorraldusele Järvamaal, ühes Eesti arheoloogiliselt kõige vähem uuritud piirkonnas. Puudulikule 
uurimisseisule vaatamata on võimalik muististe põhjal kindlaks teha omaaegseid asustuskeskusi ning vaadelda nende suhestumist teadaolevate linnamägedega, tegemaks nii oletusi linnuste rolli ja mõjuraadiuse kohta muinasaegsel Järvamaal. Looduslikke tingimusi ja muistise paiknemist aluseks võttes on võimalik kontrollida ka oletusi muinasaegse haldusjaotuse ja kihelkonnakeskuste paiknemise kohta.

Ometi ei pruugi praegu avanev pilt päriselt vastata ajaloolisele reaalsusele, sest on vägagi tõenäoline, et mitmed muistised on veel leidmata ning olemasolevad ei pruugi peegeldada reaalset olukorda. Asulakohtade ja kivikalmete dateeringud on äärmiselt umbmäärased ja pole võimatu, et mõnigi arvatav kalme osutub lähemal uurimisel lihtsalt põllukivihunnikuks. Asustuspildi uurimise seisukohalt on oluline ka arvatavate linnamägede tegeliku rolli selgitamine - arheoloogiliste kaevamistega on võimalik selgitada kaitseehitiste olemasolu või puudumine ning kultuurkihi olemasolu ja iseloom.

Arheoloogiliste uuringute taasalustamine Järvamaa linnamägedel, asulakohtadel ja kalmetel võimaldaks tulevikus ehk selgitada, kas Järva puhul oli tegemist mõne naaberpiirkonna tagamaa või hoopis omaette keskusega, millel olid oma eripärased võimustruktuurid ja halduskorraldus.

\section{Kommentaarid}

${ }^{1}$ Arheoloogilisi passe säilitatakse Ajaloo Instituudi arhiivis Tallinnas, koopiad on hoiul ka Tartu Ülikooli Arheoloogia Kabinetis.

${ }^{2}$ Maa-ameti kodulehekülg on kättesaadav aadressil www.maaamet.ee.

${ }^{3}$ Seni polnud neid avastatud ning kalme kuulumine nn kiviridakalmete hulka oli kahtluse all (Vassar 1943).

${ }^{4}$ Soode osa Kõrvemaal ulatub 40-50\%ni üldpindalast, mis teeb Kõrvemaast ühe Eesti kõige soorikkama piirkonna (Varep 1972: 21).

${ }^{5}$ Henriku Liivimaa kroonika toimetaja Enn Tarvel esitab antud peatüki (XXIV) kommentaaris oletuse, et ka hilisem Järva-Jaani kihelkond kuulus Loppegunde koosseisu. Käesolevas artiklis on siiski aluseks võetud koguteoses Eesti esiajalugu (Jaanits \& Laul \& Lõugas \& Tõnisson 1982) ja muudes kirjutistes (Vassar 1972; Tõnisson 1999) esitatud arvamus, mille kohaselt Järva-Jaani ja Koeru moodustasid omaette kihelkonna. 


\section{Priit Lätti}

\section{Kirjandus}

Einer, Väino 1988. Korilasrajast kiirteeni: [Ülevaade maailma maismaateedest]. Tallinn: Valgus.

HCL = Henriku Liivimaa kroonika = Heinrici Chronicon Livoniae. Kleis, Richard (tõlk), Tarvel, Enn (toim \& komment). Tallinn: Eesti Raamat 1982.

Jaanits, Lembit \& Laul, Silvia \& Lõugas, Vello \& Tõnisson, Evald 1982. Eesti esiajalugu: Koguteos. Tallinn: Eesti Raamat.

Jung, Jaan 1910. Muinasajateadus eestlaste maalt III: Kohalised muinasaja kirjeldused Tallinnamaalt. Tallinn: A. Buschi raamatukauplus.

Kriiska, Aivar \& Tvauri, Andres 2002. Eesti muinasaeg. Tallinn: Avita.

Lang, Valter 1996. Muistne Rävala 2: Muistised, kronoloogia ja maaviljelusliku asustuse kujunemine Loode-Eestis, eriti Pirita jõe alamjooksu piirkonnas = Prehistoric Rävala 2: Antiquities, Chronology and the Establishment of Farming Settlement in North-West Estonia, with Special Reference to the Area on the Lower Reaches of the Pirita River. Muinasaja teadus 4: Töid arheoloogia alalt 4. Tallinn: Eesti Teaduste Akadeemia.

Lang, Valter 2002a. Vakus ja linnusepiirkond Eestis: Lisandeid muistse haldusstruktuuri uurimisele peamiselt Harjumaa näitel. Lang, Valter (koost). Keskus - Tagamaa - Ä̈̈reala: Uurimusi asustushierarhia ja võimukeskuste kujunemisest Eestis = Centre - Hinterland-Margin: Studies in the Formation of Settlement Hierarchy and Power Centres in Estonia. Muinasaja teadus = Research into ancient times 11. Tallinn \& Tartu: Ajaloo Instituut \& Tartu Ülikool, lk 125-162.

Lang, Valter 2002b. Võimukeskuste kujunemisest Eestis: Sissejuhatus. Lang, Valter (koost). Keskus - Tagamaa - Ääreala: Uurimusi asustushierarhia ja võimukeskuste kujunemisest Eestis = Centre -Hinterland-Margin: Studies in the Formation of Settlement Hierarchy and Power Centres in Estonia. Muinasaja teadus = Research into ancient times 11. Tallinn \& Tartu: Ajaloo Instituut \& Tartu Ülikool, lk 7-16.

Lang, Valter \& Kriiska, Aivar 2001. Eesti esiaja periodiseering ja kronoloogia. Eesti Arheoloogia ajakiri 5: 2, lk 83-109.

Lavi, Ain 2002. Kesk-Eesti idaosa linnamägedest. Lang, Valter (koost). Keskus - Tagamaa - Ä̈reala: Uurimusi asustushierarhia ja võimukeskuste kujunemisest Eestis = Centre - Hinterland-Margin: Studies in the Formation of Settlement Hierarchy and Power Centres in Estonia. Muinasaja teadus = Research into ancient times 11. Tallinn \& Tartu: Ajaloo Instituut \& Tartu Ülikool, lk 233-267.

Lõugas, Vello \& Selirand, Jüri 1989. Arheoloogiga Eestimaa teedel. 2., täiend. trükk. Tallinn: Valgus. 
Lätti, Priit 2004a. Järvamaa muistised ja vanem asustuslugu. Remmel, Mari-Ann (koost). Arad veed ja salateed: Järvamaa kohapärimus. Tartu: Eesti Kirjandusmuuseum, lk 12-20.

Lätti, Priit 2004b. Järvamaa muistised ja asustuspilt rauaaja teisel poolel ning kesk- ja varauusajal. Bakalaureusetöö. Tartu: Tartu Ülikool. Käsikiri Tartu Ülikooli arheoloogia õppetoolis.

Mandel, Mati 2004. Läänemaa linnused ja linnusepiirkonnad. Haak, Arvi \& Russow, Erki \& Tvauri, Andres (toim). Linnusest ja linnast: Uurimusi Vilma Trummali auks = About Hillfort and Town: Studies in Honour of Vilma Trummal. Muinasaja teadus = Research into ancient times 14. Tallinn \& Tartu: Teaduste Akadeemia Kirjastus, lk 189-199.

Moora, Harri 1955. Muistsete linnuste uurimise tulemustest Eesti NSV-s. Moora, Harri \& Jaanits, Lembit (toim). Muistsed asulad ja linnused: [Artiklid]. Arheoloogiline kogumik 1. Toimetanud. Tallinn: Eesti Riiklik Kirjastus, lk 46-87.

Moora, Tanel 1966. Asustuse levimisest ühes Kesk-Eesti piirkonnas m.a. I aastatuhande esimesel poolel. Moora, Harri \& Selirand, Jüri (toim). Pronksiajast varase feodalismini: uurimusi Baltimaade ja naaberalade arheoloogiast: [pühendatud dr. Marta Schmiedehelmile 70. sünnipäevaks] = От эпохи бронзы до раннего феодализма: Исследования по археологии Прибалтики и смежных территорий. Tallinn: Eesti Raamat, lk 129-136.

Mägi, Marika 2001. At the Crossroads of Space and Time: Graves, Changing Society and Ideology on Saaremaa (Ösel), $9^{\text {th }}-13^{\text {th }}$ Centuries AD. CCC Papers 6. Tartu: University of Tartu.

Mägi, Marika 2002. Piirkonnad ja keskused: Asustust muinasaja lõpu ja varakeskaegsel Saaremaal arheoloogiliste, inimgeograafiliste ning ajalooliste allikate andmeil. Lang, Valter (koost). Keskus - Tagamaa - Ä̈̈reala: Uurimusi asustushierarhia ja võimukeskuste kujunemisest Eestis = Centre - Hinterland - Margin: Studies in the Formation of Settlement Hierarchy and Power Centres in Estonia. Muinasaja teadus = Research into ancient times 11. Tallinn \& Tartu: Ajaloo Instituut \& Tartu Ülikool, lk 169-227.

Remmel, Mari-Ann (koost) 2004. Arad veed ja salateed: Järvamaa kohapärimus. Tartu: Eesti Kirjandusmuuseum.

Saarist, Tiiu \& Tõnisson, Evald 1986. Paide rajooni ajaloo- ja kultuurimälestised. Kaitstavad mälestised. Tallinn: Eesti Raamat.

Tvauri, Andres 2002. Lõuna-Eesti noorema rauaaja linnuste ja külade arheoloogilise leiumaterjali erinevused. Lang, Valter (koost). Keskus - Tagamaa - Ääreala: Uurimusi asustushierarhia ja võimukeskuste kujunemisest Eestis $=$ Centre - Hinterland - Margin: Studies in the Formation of Settlement Hierarchy and Power Centres in Estonia. Muinasaja teadus = Research into 


\section{Priit Lätti}

ancient times 11. Tallinn \& Tartu: Ajaloo Instituut \& Tartu Ülikool, lk $275-297$.

Tõnisson, Evald 1962. Eesti aardeleiud 9.-13. sajandist. Moora, Harri (toim). Muistsed kalmed ja aarded. Arheoloogiline kogumik 2. Tallinn: Eesti NSV Teaduste Akadeemia Ajaloo Instituut, lk 182-239.

Tõnisson, Evald 1999. Järvamaa muinasaegne põllumajandus. Tõnisson, Evald \& Tarvel, Enn \& Troska, Gea (toim). Järvamaa aastal 1939 ja nü̈̈d... Tallinn: Eesti Muinsuskaitse Selts, lk 5-16.

Valk, Heiki 2004. Arheoloogilise kohainfo koondandmebaas ja andmed Lõuna-Eesti muististe kohta. Tartu Ülikooli Lõuna-Eesti keele- ja kultuuriuuringute keskuse aastaraamat III. Tartu: Tartu Ülikooli Lõuna-Eesti keele- ja kultuuriuuringute keskus, lk 135-142.

Varep, Endel 1972. Paide rajooni maastikud. Eilart, Jaan et al. (toim). Paide rajoonis: Kodu-uurijate seminari kokkutulek 6.-9. augustini 1972: Artiklite kogumik. Tartu: Eesti NSV Teaduste Akadeemia Kodu-uurimise Komisjon \& Eesti NSV Looduskaitse Selts, lk 12-36.

Vassar, Artur 1943. Nurmsi kivikalme Eestis ja tarandkalmete areng. Väitekiri. Tartu: Tartu Ülikool. Käsikiri Tartu Ülikooli raamatukogus.

Vassar, Artur 1972. Paide rajooni vanimast ajaloost (kuni XIII sajandi alguseni). Eilart, Jaan et al. (toim). Paide rajoonis: Kodu-uurijate seminari kokkutulek 6.-9. augustini 1972: Artiklite kogumik. Tartu: Eesti NSV Teaduste Akadeemia Kodu-uurimise Komisjon \& Eesti NSV Looduskaitse Selts, lk 86-106. 